\title{
Stabilisation of dissolved proteins against denaturation at hydrophobic interfaces
}

\author{
H. Thurow and K. Geisen \\ Hoechst AG, Frankfurt/Main, FRG
}

\begin{abstract}
Summary. Studies with insulin delivery devices have shown that denaturation of dissolved proteins at hydrophobic interfaces is a basic obstacle to long-term insulin stability in pumps. This study shows that polypropylene glycol/polyethylene glycol block polymers prevent both the adsorption of dissolved proteins to hydrophobic interfaces and the resultant aggregation. At a concentration of $0.001 \%(\mathrm{w} / \mathrm{v})$, the block polymer Genapol PF-10 stabilises insulin solutions over a wide range of concentrations. Insulin solutions thus stabilised
\end{abstract}

are at present being clinically tested. The effectiveness of molecular variants of Genapol PF-10 to stabilise other proteins (human $\gamma$-globulin, myoglobin and serum albumin) is presented also.

Key words: Protein denaturation, insulin stability, automatic delivery devices, insulin therapy, polypropylene glycol/polyethylene glycol block polymers.
The results obtained in recent years with programmable delivery devices for continuous insulin infusion have produced a significant advance in the treatment of insulin-dependent diabetes [13, 27]. In the future, more fields of application for programme-controlled delivery devices can be expected in drug administration. Experience with insulin pumps has shown that, for reliable, continuous administration of dissolved proteins, their denaturation at hydrophobic interfaces, causing inactivation of the hormone and occlusion of the pump system, must be prevented $[19,32]$.

The term 'denaturation of proteins in aqueous solution' describes a complex process in which the natural structure of the dissolved protein molecule is altered to such an extent that a change in its natural properties, such as biological activity and immunogenicity is entailed $[28,30]$. Proteins are amphiphilic substances, i. e. the sequence of the various amino-acids conditions the formation of hydrophilic and hydrophobic regions. The repulsive and attractive forces between these regions are balanced in the complex three dimensional structure of the native state $[1,22]$.

The denaturation at hydrophobic interfaces is initiated by the adsorption of dissolved proteins to the interface. As a consequence of adsorption, it is commonly assumed that the hydrophobic areas, preferentially located in the interior of the native protein molecule, are exposed and establish contact with the hydrophobic in- terface. In a second step, the molecules in the boundary layer subsequently aggregate over its hydrophobic areas. The aggregates eventually desorb from the surface and, above a certain concentration in the solution, precipitate or form a thixotropic gel $[7,8,12,20]$.

The surfaces of materials now used in pumps, such as delivery tubes and plastic reservoirs, have a relatively high degree of hydrophobicity. The boundary layer, such as air/solution, can be regarded also as a hydrophobic surface. When a protein solution is shaken, denaturation occurs at this surface [12]. In an earlier study [32], it was revealed that conventional neutral insulin solutions were denatured by shaking at $37^{\circ} \mathrm{C}$ for 5 days at the most. The aggregates which developed could be detected electrophoretically and could be separated from the native insulin by gel chromatography on Sephadex G-50. The aggregated, biologically inactive insulin could be renatured to the native bio-active form only under extreme conditions. We concluded that this aggregation reaction is the result of the above mentioned interface denaturation. The effects of temperature, $\mathrm{pH}$ and movement of the solution on the rate of aggregation have been described [32].

The present study shows how to prevent the adsorption of dissolved proteins, especially of insulin, to hydrophobic interfaces and the subsequent interface denaturation (aggregation). The results have already been reported in part elsewhere [11, 32]. 


\section{Materials and methods}

\section{Materials}

Bovine and porcine insulin were provided by Hoechst, Frankfurt, FRG. Human insulin was synthesised semi-synthetically from porcine insulin in the Pharma Research Department of Hoechst [21]. The insulins had been purified by gel chromatography according to the commercially available preparations of Hoechst. Egg albumin, bovine albumin, human albumin and human immunoglobulin were obtained from Behringwerke, Marburg, FRG; myoglobin and egg lecithin from Calbiochem, Marburg, FRG; stearic acid, Tween 20 and 40 and Triton WR-1339 from Serva, Heidelberg, FRG; and Genapol OX-180 from Hoechst.

The polyols of the Pluronic type were supplied by BASF Wyandotte Corporation, Leverkusen, FRG and those of the Genapol type by Hoechst. These polyols are referred to generally as polypropylene glycol/polyethylene glycol block polymers (PPG/PEG block polymers) with the following common formula [25]:<smiles>CC(O)CCC(C)(C)C(C)(C)COCC(C)C(C)(C)C(C)C</smiles>

Conditioned by the manufacturing process, they constitute a mixture of polymers of various chain lengths. Their molecular weights and the number of their $a$ and $b$ chain links are consequently mean values (Table 1).

Tetronic 1504, a product of BASF Wyandotte Corporation, is a cross-linked polyol with the following formula (mean mol. wt. $11,350)$ :

$\begin{aligned} & \mathrm{H}-\left(\mathrm{C}_{2} \mathrm{H}_{4} \mathrm{O}\right)_{26}-\left(\mathrm{C}_{3} \mathrm{H}_{6} \mathrm{O}\right)_{29} \\ & \mathrm{H}-\left(\mathrm{C}_{2} \mathrm{H}_{4} \mathrm{O}\right)_{26}-\left(\mathrm{C}_{3} \mathrm{H}_{6} \mathrm{O}\right)_{29}\end{aligned}>\mathrm{N}-\mathrm{CH}_{2} \mathrm{CH}_{2} \mathrm{~N}\left\langle\begin{array}{l}\left(\mathrm{C}_{3} \mathrm{H}_{6} \mathrm{O}\right)_{29}-\left(\mathrm{C}_{2} \mathrm{H}_{4} \mathrm{O}\right)_{26}-\mathrm{H} \\ \left(\mathrm{C}_{3} \mathrm{H}_{6} \mathrm{O}\right)_{29}-\left(\mathrm{C}_{2} \mathrm{H}_{4} \mathrm{O}\right)_{26}-\mathrm{H}\end{array}\right.$ The remaining chemicals were analytical grade products from Merck, Darmstadt, FRG.

\section{Rotation test}

To examine interface denaturation, the protein solutions $(7.0 \mathrm{ml})$ were sealed into $10.0 \mathrm{ml}$ glass ampoules (glass type I, European Pharmacopoeia, II-1971, 65, Frankfurt, FRG), so that each ampoule also contained $3.0 \mathrm{ml}$ of air. Two to five ampoules of each test solution were placed on a test tube rotator (Model H 19749, Technilab Instruments, Pequannock, New Jersey, USA) at a distance of $20 \mathrm{~cm}$ from the axle and rotated in an incubator at $37^{\circ} \mathrm{C}$ and $60 \mathrm{rev} / \mathrm{min}$. The time before visible precipitation of the rotating samples occurred was taken as a measure of the rate of denaturation [32].

For the rotation test, an insulin solution stabilised with Genapol PF-10 was prepared as follows: $400,000 \mathrm{IU}$ insulin (containing $69 \mathrm{mg}$ zinc) were dissolved in $500 \mathrm{ml}$ of $0.03 \mathrm{~N} \mathrm{HCl}$. A solution $(300 \mathrm{ml})$ of $17.0 \mathrm{~g}$ glycerol $6.057 \mathrm{~g}$ Tris-(hydroxymethyl)-aminomethane and $2.0 \mathrm{~g}$ phenol in distilled water adjusted to $\mathrm{pH} 8$ with $1 \mathrm{~N} \mathrm{HCl}$ was admixed with the insulin solution. $\mathrm{ZnCl}_{2}(31.3 \mathrm{mg})$ dissolved in $0.02 \mathrm{~N} \mathrm{HCl}$ $(\sim 30 \mathrm{ml})$ was added. The resulting mixture was adjusted to $\mathrm{pH} 7.3$ with $1 \mathrm{~N} \mathrm{HCl}$, made up to a volume of $950 \mathrm{ml}$ with distilled water and sterilised by filtration. A concentrated stock solution of Genapol PF10 was prepared by dissolving $1.0 \mathrm{~g}$ of Genapol PF-10 in 1 litre of distilled water and sterilising by filtration. To avoid a drop in the Genapol PF-10 concentration through adsorption to the filter, the first runnings were discarded. For the filtration of both solutions, a cellulose acetate filter was used (Millipore, Eschborn, FRG, pore size $0.22 \mu \mathrm{m}$; diameter $42 \mathrm{~mm}$ ). Finally, the insulin solution $(950 \mathrm{ml})$ was mixed with $10 \mathrm{ml}$ of the concentrated stock solution of Genapol PF10 and made up to 1 litre with sterile water.

Insulin solutions with additives having the same or greater solubility than Genapol PF-10 were prepared in the same way. For additives with lower solubility than Genapol PF-10, less concentrated stock solutions were used.

\section{Adsorption test with Dow latex particles}

An aqueous suspension of Dow latex beads (Serva, Heidelberg, FRG; diameter $0.481 \mu \mathrm{m}, 1.63 \times 10^{12}$ particles $/ \mathrm{ml}$, total surface area of $1.2 \mathrm{~m}^{2} / \mathrm{ml}$ ) was divided into two portions $(2 \mathrm{ml})$. One portion was shaken for 2 days with Genapol PF-10 (30 mg), and the excess Genapol PF-10 was removed by dialysis against an aqueous solution of $0.001 \%(\mathrm{w} / \mathrm{v})$ Genapol PF-10. The other $2 \mathrm{ml}$ suspension served as control. In two series of tests, 3-ml samples of an insulin solution ( $30 \mathrm{IU}$ bovine insulin $/ \mathrm{ml}$ in $0.05 \mathrm{~mol} / 1 \mathrm{Tris} / \mathrm{HCl}$ buffer, $\mathrm{pH} 7.5$ containing $0.6 \% \mathrm{NaCl}$ ) pre-cooled to $5^{\circ} \mathrm{C}$ were mixed with increasing amounts $(0-500 \mu 1)$ of either of the two Dow latex suspensions. The insulin solutions, to which the pre-treated latex suspensions had been added, contained in addition $0.001 \%$ Genapol PF- 10 . These mixtures were gently shaken for $48 \mathrm{~h}$ at $5^{\circ} \mathrm{C}$. The samples were subsequently filtered through cellulose acetate filters (pore size $0.22 \mu \mathrm{m}$ ) that had been pre-treated by filtering a $0.1 \%$ Genapol PF-10 solution (w/v) through them at $5^{\circ} \mathrm{C}$. The insulin content in the filtrates was determined by measuring the extinction at $280 \mathrm{~nm}\left(\mathrm{E}_{1 \mathrm{mg} / \mathrm{ml}}=1.00\right)$. The concentration of the unbound insulin, corrected to a sample volume of $3.0 \mathrm{ml}$, was plotted against the latex-particle surface area used in the test batch.

Table 1. Unbranched PPG/PEG block polymers tested for stabilisation of proteins against surface denaturation

\begin{tabular}{lllr}
\hline Substance & $\begin{array}{l}\text { Mean mol. wt. } \\
\text { (daltons) }\end{array}$ & \multicolumn{2}{c}{$\begin{array}{l}\text { Mean number } \\
\text { of chain links }\end{array}$} \\
\cline { 3 - 4 } & & $\mathrm{b}$ & $\mathrm{a}$ \\
\hline Pluronic L-31 & 1060 & 16.4 & 1.2 \\
Pluronic L-81 & 2500 & 38.7 & 2.8 \\
Pluronic L-101 & 3610 & 56.0 & 4.1 \\
Pluronic L-121 & 4450 & 68.9 & 5.1 \\
Genapol PF-10 & 1950 & 30.1 & 2.2 \\
Genapol PF-20 & 2190 & 30.1 & 5.0 \\
Genapol PF-40 & 2920 & 30.1 & 13.3 \\
Genapol PF-80 & 8750 & 30.1 & 80.0 \\
\hline
\end{tabular}

a, b refer to polyethylene glycol and polypropylene glycol units respectively

\section{Interaction test between Genapol PF-10 and insulin}

To examine the interaction between Genapol PF-10 and insulin in neutral solution, two series of mixtures were prepared. In the one test series, 4-ml portions of insulin solution $(50 \mathrm{IU} / \mathrm{ml}$ bovine insulin in $0.05 \mathrm{~mol} / 1 \mathrm{Tris} / \mathrm{HCl}, \mathrm{pH} 7.3$ ), were mixed with $1.5 \mathrm{ml}$ solutions of Genapol PF-10 containing 100, 75, 50,37.5 and $25 \mu \mathrm{g}$ respectively in distilled water and neutral $5 \% \mathrm{ZnCl}_{2}$ solution $(0.5 \mathrm{ml})$. In the second series, the insulin solution was replaced by $4-\mathrm{ml}$ portions of $0.05 \mathrm{~mol} / \mathrm{l}$ Tris/ $\mathrm{HCl}(\mathrm{pH} 7.3)$. Both series of mixtures were kept at room temperature for $15 \mathrm{~min}$. The amorphous zinc insulin precipitated in the first series of tests was removed by centrifugation. The Genapol PF-10 content was determined by the method of Bürger [6]. Reagent solution ( $4 \mathrm{ml})$ was added to the 4-ml portions of supernatant or control solution and the mixtures were kept for $15 \mathrm{~min}$ at room temperature. The precipitates were centrifuged and the pellets dissolved in methanol $(3 \mathrm{ml})$. The extinction of the solutions was measured at $290 \mathrm{~nm}$ against a reagent blank and the concentration of Genapol PF-10 was plotted against the amount of Genapol in the test. The molar extinction coefficient is $\varepsilon=0.10531 \cdot \mu \mathrm{mol}^{-1} \cdot \mathrm{cm}^{-1}$ and is related to the mean molecular weight (1950) for Genapol PF-10. Reagent solution: Basic bismuth nitrate $(1.7 \mathrm{~g})$ was dissolved in glacial acetic acid $(20 \mathrm{ml})$ and the solution was made up to $100 \mathrm{ml}$ with distilled water. Glacial acetic acid $(40 \mathrm{~g})$ and distilled water $(600 \mathrm{ml})$ were added and two portions of this solution were mixed with one portion of $20 \%$ barium chloride solution. 
Table 2. The stabilisation of insulins of various species and concentrations by $0.001 \%$ Genapol PF- $10(\mathrm{w} / \mathrm{v})$ at $37^{\circ}$

\begin{tabular}{lll}
\hline $\begin{array}{l}\text { Insulin (concentrations) in: } \\
0.05 \mathrm{~mol} / \mathrm{I} \text { Tris } / \mathrm{HCl} \text { buffer }(\mathrm{pH}\end{array}$ & $\begin{array}{l}\text { Turbidity } \\
\text { after } \\
\text { (days) }\end{array}$ & $\begin{array}{l}\text { Intravenous bio- } \\
\text { logical activity in } \\
\text { the rabbit }(\%)\end{array}$ \\
$\begin{array}{lcl}1.7 \% \text { glycerol and } 0.2 \% \text { phenol } \\
\text { Without Genapol } P F-10:\end{array}$ & $2-5$ & $<5$ \\
Porcine $\left(40 ; 400^{\mathrm{a}} ; 1000 \mathrm{IU} / \mathrm{ml}\right)$ & $2-5$ & $<5$ \\
Bovine $\left(40 ; 100^{\mathrm{a}} ; 400 \mathrm{IU} / \mathrm{ml}\right)$ & & \\
With Genapol $P F-10:$ & $400-450$ & 100 \\
Bovine $\left(100^{\mathrm{a}} ; 400 \mathrm{IU} / \mathrm{ml}\right)$ & $>180$ & 100 \\
Porcine $\left(100^{\mathrm{a}} ; 400 ; 1000 \mathrm{IU} / \mathrm{ml}\right)$ & $>100$ & \\
Human $(1.5 \mathrm{mg} / \mathrm{ml})$ & & \\
\hline
\end{tabular}

a denotes relevant concentration at which bioactivity was determined

\section{Test for biological insulin activity}

The biological activity of the insulins was tested intravenously in rabbits according to Smith [26].

\section{Results}

The effect of Genapol PF-10 on insulin denaturation in the rotation test

Genapol PF-10 protects insulin against denaturation in the rotation test. The stabilising effect of Genapol PF-10 could be demonstrated for bovine, porcine and human insulin. Solutions with different insulin concentrations up to $1,000 \mathrm{IU} / \mathrm{ml}$ are stabilised by $0.001 \%$ Genapol PF-10 (w/v) (Table 2).

The molar ratio insulin/stabilisor in the insulin solution containing $1,000 \mathrm{IU} / \mathrm{ml}$ is $1,260: 1$. The biological activity in the stabilised insulin solutions tested is maintained in full after the rotation period specified. When unstabilised, these insulin solutions are turbid after a few days and biologically scarcely active. Admixtures of $0.0002 \%$ egg lecithin, $0.01 \%$ stearic acid, $0.01 \%$ Triton WR-1339, $0.01 \%$ Tween $20,0.01 \%$ Tween 40 or $0.1 \%$ Genapol OX-180 do not stabilise bovine insulin in the same solution medium.

\section{Insulin-stabilising effect of polypropylene} glycol/polyethylene glycol block polymers depending on molecular variations and their concentrations in the rotation test

The optimal Genapol PF-10 concentration is about $0.001 \%(\mathrm{w} / \mathrm{v})$. The concentration of $0.01 \%$ Genapol PF$10(\mathrm{w} / \mathrm{v})$ has no stabilising effect since it is higher than the micelle concentration of $0.0014 \%$ [25].

The test with Pluronic polyols shows that the length of the central PPG chain has a marked influence on the stabilising properties (Table 3 ). The optimal PPG chain length seems to be between 16 and 38 chain links. Gena-
Table 3. Effect of molecular analogues of Genapol PF-10 in various concentrations on the stabilisation of bovine insulin in the rotation test at $37^{\circ} \mathrm{C}$

\begin{tabular}{lll}
\hline Product & $\begin{array}{l}\text { Concentration of } \\
\text { additives }(\% \mathrm{w} / \mathrm{v})\end{array}$ & $\begin{array}{l}\text { Turbidity } \\
\text { after } \\
\text { (days) }\end{array}$ \\
\hline
\end{tabular}

Bovine insulin solution:

$400 \mathrm{IU} / \mathrm{ml} ; 84 \mu \mathrm{g} \mathrm{Zn} / \mathrm{ml}$;

$0.05 \mathrm{~mol} / 1 \mathrm{Tris} / \mathrm{HCl}(\mathrm{pH} 7.3)$;

$1.7 \%$ glycerol; $0.2 \%$ phenol

Without additive:

With additive:

Genapol PF-10

Pluronic L-31

Pluronic L-81

Pluronic L-101

Pluronic L-121

Genapol PF-20

Genapol PF-40

Genapol PF-80

\begin{tabular}{lcc} 
& 0.01 & 2 \\
& 0.1 & 2 \\
& 1 & 7 \\
Tetronic 1504 & 10 & 9 \\
& 0.001 & 4 \\
PPG (mol.wt. 2100 daltons) & 0.01 & 5 \\
PEG (mol.wt. 2000 daltons) & 0.1 & 25 \\
& 0.0003 & 7 \\
& 0.001 & 2 \\
PEG (mol.wt. 6000 daltons) & 0.01 & 2 \\
& 1 & 2 \\
& 10 & 2 \\
& 1 & 2 \\
\hline
\end{tabular}

pol PF-10 with 30 PPG chain links (1750 daltons) stabilises the insulin solutions in the rotation test over more than 450 days. In the series of polyols with an increasing PPG chain length, Genapol PF-10 can be classified between Pluronic L-31 and Pluronic L-81 (Table 1). Tests on the effect of the length of the PEG chains grafted on both sides of the central PPG chain on the insulin-stabilising effect show an optimum less than 5 chain links. A PPG chain (36 chain links; 2,100 dalton) without PEG side chains has, on account of the substance's poor solubility, only a slight stabilising effect. Genapol PF-20 with a five-link PEG chain also has a weaker stabilising effect on insulin than Genapol PF-10. As the length of the PEG chains increases, the effect rapidly decreases. Pure PEG chains with a molecular weight of 2,000 and 6,000 have no stabilising effect. 


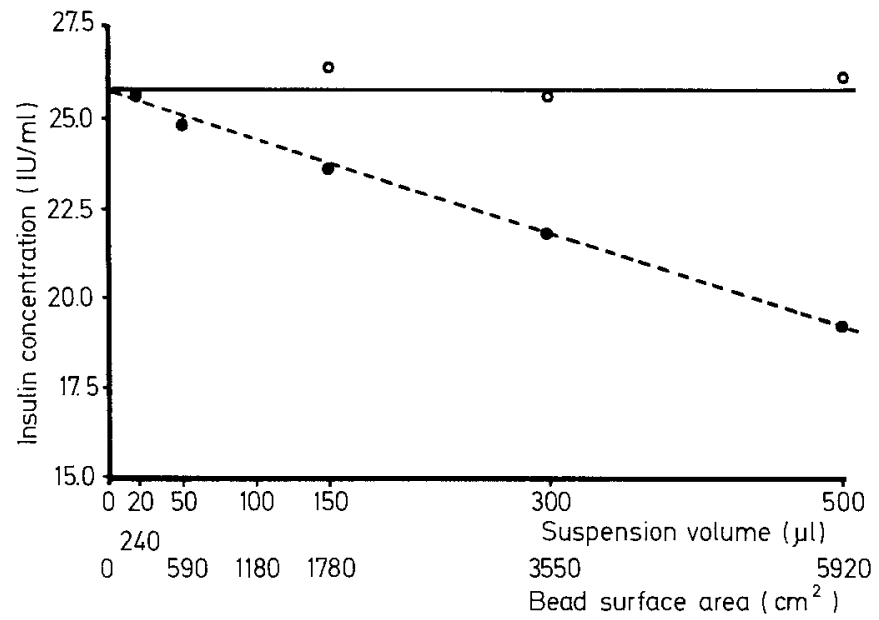

Fig. 1. The effect of Genapol PF-10 on the adsorption of insulin to increasing surface areas of Dow latex beads after $48 \mathrm{~h}$ incubation at $5^{\circ} \mathrm{C}$. $\mathrm{O}-\mathrm{O}$ with Genapol PF-10; -..- without Genapol PF-10; coefficient of regression for insulin adsorption in the absence of Genapol PF-10:

$-\frac{0.261}{5290} \mathrm{mg} \cdot \mathrm{ml}^{-1} \cdot \mathrm{cm}^{-2}$

\section{Insulin adsorption to Dow latex particles}

Insulin from an aqueous neutral solution adsorbs to the polystyrene surface of Dow latex particles. In the range examined, the amount of adsorbed insulin correlated linearly with the surface area (Fig. 1). From the coefficient of the regression line and from the molecular weight of insulin $(5,734)$, the surface area covering one of the 51 insulin amino-acids is calculated to be $14.2 \AA^{2}$. This value correlates well with the data found in the literature $[5,8]$. In contrast, under otherwise identical test conditions, insulin, in the presence of $0.001 \%$ Genapol PF-10 (w/v), did not adsorb to the surface of latex particles coated with Genapol PF-10.

\section{Exclusion of the interaction of Genapol PF-10 with insulin}

Genapol PF-10 was determined in solutions of increasing concentrations $(2.14-8.55 \mathrm{nmol} / \mathrm{ml})$. When the Genapol solutions contain, in addition, a constant amount of insulin $(230 \mathrm{nmol} / \mathrm{ml})$ and this is precipitated as amorphous zinc insulin, the Genapol PF-10 concentrations in the supernatants are identical to those in the insulin-free control solutions (Fig. 2). We conclude from this that insulin precipitated from neutral solution does not bind Genapol PF-10 under the test conditions.

\section{Discussion}

A number of ways of preventing denaturation of insulin at interfaces have been suggested $[2,3,4,17,18,24]$. Although acidic insulin solutions and neutral solutions of sulphated insulins [2] clearly remain in solution over a relatively long period of time in the rotation test, they

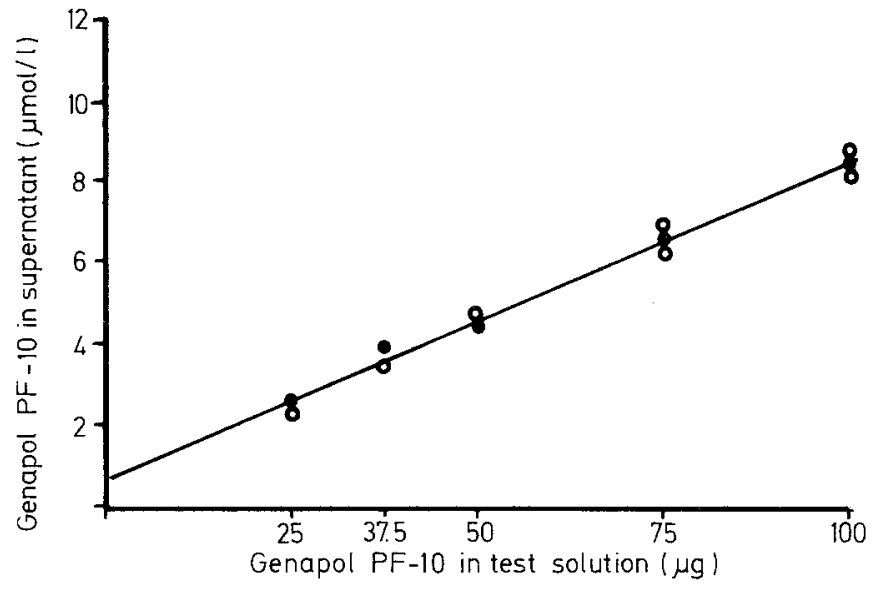

Fig. 2. Exclusion of interaction of Genapol PF-10 with dissolved insulin. Recovery of Genapol PF-10 in the supernatant after precipitation of insulin with zinc ions; O Concentration of Genapol PF-10 in the supernatant after insulin precipitation; concentration of Genapol PF-10 in the absence of insulin

do lose their biological activity as the study advances [2, 9]. The admixture of amino-dicarbonic acids [4], urea [24], $\mathrm{Zn}^{++}$ions [32] and $\mathrm{Ca}^{++}$ions [3] do not have an adequate stabilising effect [11,32].

An aqueous solution of native insulin represents a reversible equilibrium state of monomeric, dimeric, tetrameric and hexameric forms of the hormone. The equilibria are effected by the insulin concentration, $\mathrm{pH}$ value and ionic strength of the solution $[14,15]$. There are indications that the dimeric form of insulin is adsorbed to hydrophobic interfaces [5] and subsequently aggregates to high-molecular weight forms in the adsorbed protein film (Fig. 3).

Therefore, one possibility to retard the surface denaturation process should be to lower the concentration of the dimeric form in the solution. Indeed, it has been reported that urea in a certain concentration [24] and some detergents [17] increase to a certain extent the stability of the insulin solutions coming in contact with hydrophobic surfaces. These additives shift the self-association equilibria of insulin in the direction of the monomeric form by interacting with the insulin molecule. But higher concentrations of most of these substances cause a denaturation of insulin in solution [17, 24, 32]. Additives such as zinc ions [32], calcium ions [3] and some other divalent metal ions, which shift the selfassociation equilibria of insulin in the direction of the hexameric form, also show a slight but insufficient stabilizing effect $[11,32]$.

Another possibility of retarding or even preventing denaturation is to inhibit protein adsorption to hydrophobic interfaces by adding amphiphilic surface-active substances to the protein solution. These adsorb to the interface and transform its hydrophobic property into a hydrophilic one. By adding albumin in relatively high 
Hydrophobic surface

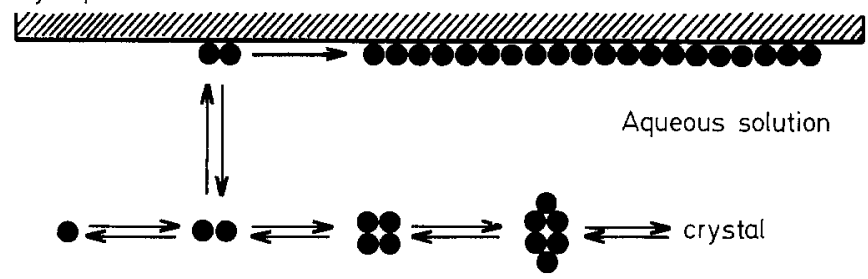

Fig. 3 Reversible self-association of insulin, its adsorption to the hydrophobic interface and irreversible aggregation in the adsorbed protein film; represents a monomeric insulin molecule

concentrations, insulin adsorption can, for example, be suppressed. The albumin, however, ultimately denatures at the same time [33,34]. Human albumin is apparently more suitable for this purpose than bovine or egg albumin (Table 4). The adsorption can also be prevented by loading the interface with higher alkanols [7] or detergents [23, 29]. However, as mentioned above, most of these additives interact with insulin because of their high hydrophobicity causing the denaturation of insulin

Table 4. Stabilisation of various proteins by Genapol PF-10 and its molecular analogues in the rotation test at $37^{\circ} \mathrm{C}$

\begin{tabular}{lll}
\hline Product & $\begin{array}{l}\text { Concentration of } \\
\text { additive }(\% \mathrm{w} / \mathrm{v})\end{array}$ & $\begin{array}{l}\text { Turbidity } \\
\text { after } \\
\text { (days) }\end{array}$ \\
\hline
\end{tabular}

Egg albumin $5 \mathrm{mg} / \mathrm{ml}$;

phosphate buffer ( $\mathrm{pH} 7.2)$

Without additive

With Genapol PF-10

With Genapol PF-80

With Tetronic 1504

$\begin{array}{lr} & 2 \\ 0.001 & 1^{\mathrm{a}} \\ 0.1 & >270 \\ 0.1 & >270\end{array}$

Bovine serum albumin $5 \mathrm{mg} / \mathrm{ml}$,

phosphate buffer ( $\mathrm{pH} 7.2$ )

Without additive

With Genapol PF-10

0.001

6

Human serum albumin $5 \mathrm{mg} / \mathrm{ml}$,

phosphate buffer ( $\mathrm{pH} 7.2$ )

Without additive

With Genapol PF-10

0.001

67

Myoglobin (horse) $5 \mathrm{mg} / \mathrm{ml}$, phos-

phate buffer (pH 7.2)

Without additive

With Genapol PF-10

With Genapol PF-80

With Tetronic 1504

$\begin{array}{ll} & 1 \\ 0.001 & 1^{\mathrm{a}} \\ 0.1 & >200 \\ 0.01 & >130\end{array}$

Human $\gamma$-globulin $5 \mathrm{mg} / \mathrm{ml}$, phos-

phate buffer ( $\mathrm{pH} 7.2$ )

Without additive

With Genapol PF-10

With Genapol PF-80

With Tetronic 1504

\begin{tabular}{lr} 
& \multicolumn{1}{c}{${ }^{\mathrm{a}}$} \\
0.001 & $>288$ \\
0.1 & $>157$
\end{tabular}

Glucagon $1 \mathrm{mg} / \mathrm{ml}, 0.05 \mathrm{~mol} / 1$

Tris/ $\mathrm{HCl}(\mathrm{pH} 8.0)$

Without additive

With Genapol PF-10

0.003

4

${ }^{a}$ In these samples spontancous turbidity occurred in solution. Hence, additives such as lecithin, stearic acid and some other detergents to insulin solution have proved to be ineffective in the rotation test (Table 2).

The prerequisite for optimal loading of the interface (extreme hydrophobicity of the additives) and for as weak a binding as possible to the hydrophobic regions of the dissolved proteins (low hydrophobicity of the additives) is met by PPG/PEG block polymers.

The insulin adsorption test on Dow latex particles consequently shows that sufficient loading of the particle surface with Genapol PF-10 completely prevents insulin adsorption (Fig. 1). Sufficient loading means here a degree of saturation of the surface which is in equilibrium with the concentration of $0.001 \%$ Genapol PF- 10 in the solution. Consequently hydrophobic surfaces of pump compartments should be sufficiently loaded before having contact with stabilised insulin solution.

Since the Genapol PF-10 content of a neutral insulin solution does not change after removing the insulin by precipitation with zinc ions, we assume that there is no significant interaction between insulin and Genapol PF-10 (Fig. 2). A small portion of the precipitated insulin $(<3 \%)$ remains in the supernatant, so we cannot rule out the possibility that this forms an associate with Genapol PF-10. Neither can we exclude the fact that the incubation time is too short to achieve equilibrium. Appropriate investigations in connection with long-term stability testing have not yet been concluded. Results obtained so far, however, do not contradict this statement. The assumption of non-interference is backed by the molar ratio of insulin to Genapol PF-10 in the highly concentrated insulin solutions (up to 1,260:1) and by the apparent non dependency of the effective stabiliser concentration $(0.001 \%, \mathrm{w} / \mathrm{v})$ on the insulin concentration (Table 2). It is supported also by the fact that the crystallization process of zinc-insulin at $\mathrm{pH} 5.4$ is not prevented by $0.001 \%(\mathrm{w} / \mathrm{v})$ Genapol PF-10 (unpublished results).

Our hypothetical conception is that the active principle of the PPG chain is based on the alternating arrangement of slightly hydrophobic lateral methyl groups and hydrophilic oxygen bridges. We assume that the lateral methyl groups have contact to the hydrophobic interface and that the oxygen bridges rise into the aqueous phase and impart hydrophilic properties to the interface (Fig. 4). The sum of the low linkage forces of the individual methyl groups of the chain results in a strong binding to the interface. The relatively small hydrophobic areas of the dissolved proteins compared to the interface permit contact with only a few methyl groups of the PPG chain, so that the resultant linkage force, compared with that to the interface, in most cases can be disregarded [29].

The PPG-chain of Genapol PF-10 is evidently responsible for the stabilising effect. Hence, in the rotation test, a pure PPG chain of mol. wt. 2,100 at a concentration of $0.0003 \%(\mathrm{w} / \mathrm{v})$ shows an insulin-stabilising effect which, although slight, is noticeable. Pure 


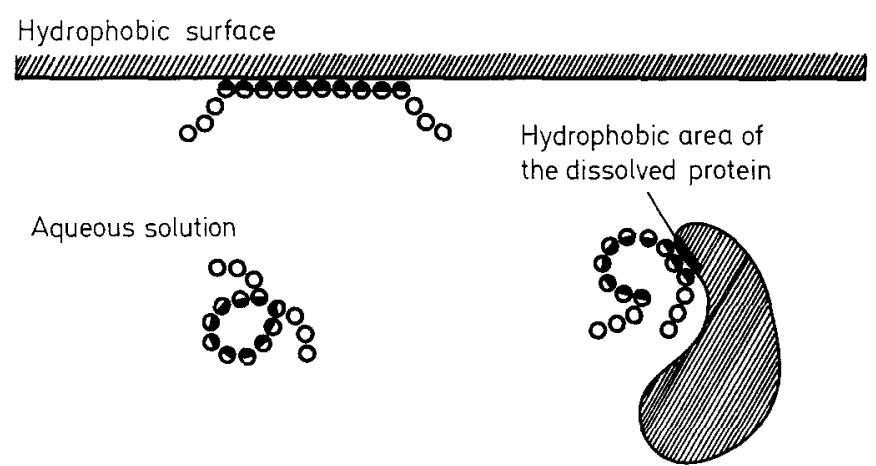

Fig. 4. Hypothetical conception of the principle of preventing adsorption of dissolved proteins to hydrophobic interfaces by means of PPG/PEG block polymers; $\odot$ PPG-Monomer; $O$ PEG-Monomer

PEG chains of mol. wt. 2,000 and 6,000 are, on the other hand, ineffective (Table 3 ).

Similarly, as in the case of dissolved proteins, two different structures of PPG/PEG block polymers exist - a globular structure in the solution and a meandrous unfolded structure at the interface [25]. The tests on the dependency of the stabilising effect of PPG/PEG block polymers on molecular variations show the strong effect of a PPG-chain length of approximately 30 links (Table 3). We assume that shorter PPG chains, on account of the smaller number of lateral methyl groups, do not have sufficient linkage force to the interface and that longer PPG chains lend to the ball structure in the solution such a high stability that sufficient loading of the interface is therefore not possible. The lateral PEG chains give the block polymers a greater water-solubility, which increases with the length of the PEG chains [25].

Genapol PF-10, with its short PEG side chains, stabilised lower molecular peptides (such as glucagon and insulin) and some higher-molecular proteins such as bovine and human albumin but not egg albumin, horse myoglobin and human immunoglobulins. Genapol PF80 , with its longer PEG side chains, apparently protects only higher molecular proteins such as egg albumin, horse myoglobin and human immunoglobulins (Table 4).

In general, the results of the test show that PPG/ PEG block polymers are able to prevent both the adsorption of dissolved proteins to hydrophobic interfaces and the resultant aggregation. The stabiliser must however, be optimised for each protein; for low molecular weight peptides short PEG side chains seem to be suitable but for high molecular weight proteins, longer PEG side chains or cross-linked chains stabilise [31].

Genapol PF-10 has already been tested over a relatively long period of time in animal [10] and human studies [13] as stabiliser in the utilisation of neutral insulin solutions in implanted and externally portable delivery devices. By solving the basic problem of adsorption and denaturation of insulin at hydrophobic interfaces, the main cause of the precipitation of insulin in the catheter and reservoir of delivery devices would seem to be eliminated. Problems which have cropped up with stabilised insulin preparations in several pumps are the subject of further investigations.

The present study does not deal with the denaturation of dissolved proteins based on surface properties other than hydrophobicity. For example, denaturation initiated by proteins binding to electrically charged surfaces cannot be prevented by the stabilisers described. It is, for instance, well known that commercial silicone, to which loaded silicate has been added as filler, is, on account of its negative surface charge, less compatible with plasma proteins than filler-free products [16]. Plastic materials coming in contact with protein solutions should also be examined to ascertain whether or not they emit low-molecular substances which could cause protein denaturation in solution [28].

\section{References}

1. Adams MJ, Blundell TL, Dodson EJ, Dodson GG, Vijayan M, Baker EN, Harding MM, Hodgkin DC, Rimmer B, Sheat S (1969) Structure of rhombohedral 2 zinc insulin crystals. Nature 224: 491-495

2. Albisser AM, Lougheed WD, Chow JC, Tung AK (1982) A modified insulin for pumps. Diabetes 31 (Suppl 2): $67 \mathrm{~A}$

3. Brange J, Havelund S (1983) Insulin pumps and insulin quality requirements and problems. Acta Med Scand (Suppl) 671: 135-138

4. Bringer J, Heldt A, Grodsky GM (1981) Prevention of insulin aggregation by dicarboxylic amino acid during prolonged infusion. Diabetes 30: 83-85

5. Browne M, Cecil R, Miller JC (1973) Some reaction of insulin at non-polar surfaces. Eur J Biochem 33: 233-240

6. Bürger K (1963) Spurennachweis und quantitative Bestimmung von grenzflächenaktiven Polyäthylenoxidverbindungen und von Polyäthylenglykolen. Z Anal Chem 196: 251-259

7. Cecil R, Louis CF (1970) Protein-hydrocarbon interactions. Biochem J 117: 147-156

8. Cumper CWN, Alexander AE (1950) The surface chemistry of proteins. Trans Faraday Soc 46: 235-253

9. Galloway JA, Root MA, Chance RE, Jackson RL, Wentworth SM, Davidson JA (1975) New forms of insulin. In: Krysten LJ, Shaw RA (eds) Endocrinology and Diabetes. Grune \& Stratton, New York, pp 329-342

10. Geisen K, Thurow H, Jung S (1982) A remote programmable implantable insulin dosing device, part II: results of animal experiments. In: Federlin K, Pfeiffer EF, Raptis S (eds) Islet-pancreastransplantation and artificial pancreas, Workshop Vouliagmeni Beach/Athens 1980, Horm Metab Res (Suppl, Ser Vol) 12: 308-312

11. Grau U, Seipke G, Obermeier R, Thurow H (1982) Stabile Insulinlösungen für automatische Dosiergeräte. In: Petersen $\mathrm{KG}$, Schlüter KJ, Kerp L (eds) Neue Insuline: 1. Internationales Symposium, Freiburg, Germany, 4.-5. Dezember 1982, Freiburger graphische Betriebe, pp 411-419

12. Henson AF, Mitchell JR, Mussellwhite PR (1970) The surface coagulation of proteins during shaking. J Colloid Interface Sci 32: $162-165$

13. Irsigler K, Kritz H, Hagemüller G, Franetzki M, Prestele K, Thurow H, Geisen K (1981) Long-term continuous intraperitoneal insulin infusion with an implanted remote-controlled insulin infusion device. Diabetes 30: 1072-1075

14. Jeffrey PD (1974) Polymerization behaviour of bovine zinc-insulin 
at neutral pH. Molecular weight of the subunit and the effect of glucose. Biochemistry 13: 4441-4447

15. Jeffrey PD, Milthorpe BK, Nichol LW (1976) Polymerization pattern of insulin at $\mathrm{pH} 7.0$. Biochemistry 15: 4660-4665

16. Kolobow T, Stool EW, Weathersby PK, Pierce J, Hayano F, Suaudeau J (1974) Superior blood compatibility of silicone rubber free of silica filler in the membrane lung. Trans Am Soc Artif Int Organs 20: 269-276

17. Lougheed WD, Albisser AM, Martindale AM, Chow IC, Clement JR (1983) Physical stability of insulin formulations. Diabetes 32: $424-432$

18. Lougheed WD, Fischer U, Perlmann K, Albisser AM (1981) A physiological solvent for crystalline insulin. Diabetologia 20: $51-53$

19. Lougheed WD, Woulfe-Flanagan H, Clement JR, Albisser AM (1980) Insulin aggregation in artificial delivery systems. Diabetologia 19: 1-9

20. MacRitchie F (1978) Proteins at interfaces. Adv Protein Chem 32: 283-326

21. Obermeier R, Geiger R (1976) A new semisynthesis of human insulin. Hoppe-Seyler's Z Physiol Chem 357: 759-767

22. Ramachandran GN, Sasisekharan V (1968) Conformation of polypeptides and proteins. Adv Protein Chem 23: 283-437

23. Reynolds JA, Herbert S, Polet H, Steinhardt J (1967) The binding of divers detergent anions to bovine serum albumin. Biochemistry $6: 937-947$

24. Sato SH, Ebert CD, Kim SW (1983) Prevention of insulin self-association and surface adsorption. J Pharm Sci 72: 228-232

25. Schmolka IR (1967) Polyalkylene oxide block copolymers. In: Schick MJ (ed) Nonionic surfactants, Vol I. Dekker, New York, pp 300-371

26. Smith KL (1962) Insulin. In: Dorfman RI (ed) Methods in hormone research, Vol II: Bioassay. Academic press, New York London, pp 413-457
27. Symposium on Insulin Delivery Devices (1980) Proceedings of the Kroc Foundation International Conference. Diabetes Care 3: 253-320

28. Tanford C (1968) Protein denaturation. Adv Protein Chem 23 : 121-282

29. Tanford C (1972) Hydrophobic free energy, micelle formation and the association of proteins with amphiphiles. J Mol Biol 67: 59-74

30. Tanford C (1970) Protein denaturation. Adv Protein Chem 24: $1-95$

31. Thurow $H$, Hoechst AG, Frankfurt, FRG. Patent disclosures DE 2917535 A1 and EP 0018609 B1, European Patent Office, Munich, FRG

32. Thurow H (1980) Studies on the denaturation of dissolved insulin. In: Brandenburg D, Wollmer A (eds) Insulin, chemistry, structure and function of insulin and related hormones: Proceedings of the second International Insulin Symposium, Aachen, Germany, September 4-7, 1979, De Gruyter, Berlin New York, pp 215-221

33. Weisenfeld S, Podolsky S, Goldsmith L, Ziff L (1968) Adsorption of insulin to infusion bottles and tubing. Diabetes 17: 766-771

34. Wishnia A, Pinder T (1964) Hydrophobic interactions in proteins: conformation changes in bovine serum albumin below pH 5. Biochemistry $3: 1377-1384$

Received: 23 March 1983

and in revised form: 24 May 1984

Dr. H. Thurow

Hoechst $A G$

Abteilung für Pharmakologie, H 821

Postfach 800320

D-6230 Frankfurt (M) 80

FRG 